\title{
Research ethics and resource allocation in times of covid-19
}

\author{
Mariana Cabral Schveitzer ${ }^{1}$, Beatriz da Costa Thome \\ 1. Universidade Federal de São Paulo, São Paulo/SP, Brazil.
}

\begin{abstract}
The purpose of this reflection is to include ethical principles in the discussion on resource allocation in times of covid-19. This study presents recent news and documents on the use of resources in the pandemic and principles such as justice, autonomy and beneficence. The comprehension that all human beings are worthy of respect, solidarity and protection can help pave the way for accelerating pandemic control for all.
\end{abstract}

Keywords: Coronavirus infections. Bioethics. Social justice.

\section{Resumo}

Ética em pesquisa e alocação de recursos em tempos de covid-19

O objetivo desta reflexão é incluir princípios éticos na discussão sobre alocação de recursos em tempos de covid-19. Este estudo apresenta notícias e documentos recentes sobre uso de recursos na pandemia, e princípios como justiça, autonomia e beneficência. A compreensão de que todos os seres humanos merecem respeito, solidariedade e proteção pode ajudar a trilhar caminhos que acelerem o controle da pandemia para todos.

Palavras-chave: Infecções por coronavírus. Bioética. Justiça social.

\section{Resumen}

Ética de investigación y asignación de recursos en tiempos de covid-19

El propósito de esta reflexión es incluir principios éticos en la discusión sobre la asignación de recursos en tiempos de covid-19. Se trata de un estudio que presenta noticias y documentos recientes sobre el uso de recursos en la pandemia y sobre principios como justicia, autonomía y beneficencia. La comprensión de que todos los seres humanos son dignos de respeto, solidaridad y protección puede ayudar a allanar el camino para acelerar el control de la pandemia para todos.

Palabras clave: Infecciones por coronavírus. Bioética. Justicia social. 
In his book Justice ${ }^{1}$, Michael J. Sandel presents Immanuel Kant's comprehension of justice as the preservation of human rights, independently of where people live and despite the knowledge, interest or objective one has towards another, simply because they are human and worthy of respect. According to Sandel ${ }^{1}$, Kant's conception is contrary to the idea of humans being used as instruments of collective happiness, as proposed by utilitarianism and defended by John Stuart Mill. The contradiction refers to the attempt to base moral values in personal interests or desires, such as happiness or utility, since they are determined by external forces or circumstantial needs. For Kant, to act autonomously one's attitudes should not be based in particular needs, but in a way that treats humanity as an end, in opposition to mere means.

In a world where different theories dispute moral arguments, we must look deeper into social values to defend the rights to health and care. In this sense, we should improve our discussions and understanding of justice ${ }^{1}$, solidarity ${ }^{2}$ and social responsibility ${ }^{3}$, even in a context in which utilitarianism prevails over Kantianism in general - the first based in the idea of promoting happiness and minimizing suffering (but only for some people) ${ }^{4}$.

Autonomy, beneficence and non-maleficence play an important role in this discussion the first considered from a Kantian deontological ethics perspective, and the others as utilitarian. Mandal, Ponnambath and Parija ${ }^{5}$ defend that deontology would be more patient-centered and utilitarianism would be more closely related to society, whereas a balance between these two perspectives could bring better harmony and justice to medical practice. However, Dawson and Jennings ${ }^{2}$ urge us to go beyond these principles in order to bring solidarity for public health ethics.

Health professionals and researchers should all feel the same indignation as shown by Tedros Adhanom Ghebreyesus, World Health Organization (WHO) director-general, about the statement of a French doctor justifying the conduct of experiments to develop a vaccine for covid-19 in an African population ${ }^{6}$. This justification is dehumanizing and puts the autonomy of an entire continent at risk. Why can vulnerability justify testing but not prioritizing the same people for vaccination?

Ethical double standard in multinational clinical trials is an instance of moral imperialism and persistent colonialist thinking that must be rejected $^{7}$. For this reason, the objective of this article is to highlight some fundamental aspects to guide research ethics and the allocation of resources in the covid-19 pandemic.

\section{Research ethics}

Since 1964, the Declaration of Helsinki ${ }^{8}$ has been accepted internationally as the democratic and equanimous keystone of scientific research with human subjects. However, the impact of economic fundamentalism exercised by wealthy countries led to an inevitably ethical double standard, exposing communities of poor countries to even greater vulnerability, discrimination and social exclusion?

This fundamentalism has influenced the revision of the Declaration of Helsinki without completely protecting human participants in lowand middle-income countries, facilitating their abuse and exploitation, as well as the outsourcing of risks (as the French doctor proposed ${ }^{6}$ ), and generating less benefits for them ${ }^{10}$.

The Belmont Report ${ }^{11}$ presents the principles of autonomy, beneficence and justice related to scientific research with human subjects. The first advocates for the respect of people's autonomy and the protection of those whose autonomy is reduced. An autonomous person is understood as an individual capable of deciding on their personal goals and acting under the guidance of this decision. The report's concept of autonomy is empirical - an action becomes autonomous only after informed consent. Beneficence means not causing harm, maximizing benefits and minimizing risks. Regarding justice, Sandel ${ }^{1}$ points out that utilitarians define it based on the "maximization" of opportunities; John Rawl's "fair distribution" can be considered deontological, and Aristotle acknowledges that like people should be treated alike.

These principles have gone a long way, following social, cultural and economic changes in society, and were mainly discussed in the 
Universal Declaration on Bioethics and Human Rights, mainly in its tenth article: the fundamental equality of all human beings in dignity and rights is to be respected so that they are treated justly and equitably ${ }^{12}$. However, the challenges to apply these principles, considering sanitary, social and environmental aspects, are still faced by people all over the world ${ }^{12}$.

\section{Resources allocation}

The Nuffield Council on Bioethics ${ }^{13}$ recently published the report Research in global health emergencies: ethical issues to guide research in emergency situations and expand the Belmont Report's fundamental principles with an "ethical compass" based on equal respect, fairness, and help to reduce suffering. The document also presents ethical aspects relevant to the development of research plans involving covid-19: solidarity, community involvement, data sharing and transparency, setting priorities and supporting health professionals ${ }^{14}$.

In addition, Emanuel and collaborators analyzed proposals for resources distribution in pandemics and other scenarios of absolute scarcity and structured them on four fundamental values: maximizing the benefits produced by scarce resources, treating people equally, promoting and rewarding instrumental value [health professionals, for example] and giving priority to the worst off ${ }^{15}$. These procedures must be transparent to ensure the public's confidence in justice. The authors also emphasize the consensus that a person's wealth should not determine who lives or dies, and disagree with the idea of attending first who arrives first, as it can generate panic and violence ${ }^{16}$.

It is imperative to update these guidelines to deconstruct the colonizer's discourse that tries to justify the use of African populations as human guinea pigs, placing the entire continent in an inferior position and disregarding their autonomy and existence. The Tuskegee study ${ }^{17}$, the infamous syphilis investigation, is one example of African American population being left untreated to study the natural history of a disease. The risk increases in a pandemic situation, considering all the impacts caused by covid-19 in the world. For this reason, health professionals and researchers should continue in the relentless struggle to guarantee ethical research for each individual, especially vulnerable populations.

\section{Vaccine prioritization}

With the development of vaccines against covid-19, some questions emerge about priority populations and the rationale involved in this logic. The WHO Working Group on Ethics and Covid-19 ${ }^{18}$ states that a fair system engenders solidarity, trust, transparency, inclusiveness, consistency and accountability. Countries should collaborate globally to mitigate the outbreak, and vaccines should be allocated to maximize benefits, considering the individuals who are at risk of becoming infected and seriously ill, followed by those who, if vaccinated, would help to stop the spread of the virus. In addition, we should consider those who volunteered to participate in research aimed at developing vaccines.

Nevertheless, many high income (and some middle income) countries are making direct vaccine purchase deals with pharmaceutical companies to ensure enough supply to vaccinate its population a couple of times over, in some cases ${ }^{19}$. These agreements reflect what has been called "vaccine nationalism" ${ }^{20}$, implying that some rich nations can have first access to vaccines despite the real claims of those that need it the most, such as elderly people, people with comorbidities, and healthcare professionals. This situation has happened before, when H1N1 vaccines were developed and rich countries hoarded the supply and only later African countries had access to them.

Moreover, the prices and conditions needed to offer the developed vaccines also promote inequality. Emerging countries, such as India and South Africa, called for the suspension of patent rules for vaccines, drugs, tests and treatments against covid-19 until herd immunity is reached in the world population. The World Trade Organization leads the negotiation, with the support of the WHO. However, Brazil did not adhere to the project ${ }^{21}$. 


\section{Equitable access}

Utilitarianism, imperialism, colonialist thinking and economic fundamentalism can help to understand why movements like vaccine nationalism rise ("my country's happiness first"). Only universal human rights as valued by Kantianism, solidarity in public health and "fair distribution" of justice can help to control covid-19 in the medium-term, that is, no one is safe until everyone is safe ${ }^{22}$. The WHO Access do Covid-19 Tools (ACT) Accelerator Program ${ }^{22}$ defends global collaboration to expedite development, production and equitable access to covid-19 tests, treatments and vaccines. The Covax Facility stands as the pillar within the WHO ACT Accelerator that aims at ensuring fair vaccine distribution ${ }^{23}$.

However, isolated programs might not be enough to change the social and economic roots that cause vulnerability in specific geographical areas and communities. Latin American researchers propose the "principle of protection" as a conceptual and analytical tool to address moral problems related to public health, especially in cases of vulnerability and deprivation, which currently stand out due to their relevance in the pandemic ${ }^{24}$. This principle requires clear identification of objectives (what should be protected) and actors involved (who should protect and to whom the protection will be directed) in its implementation, being thus sufficient to justify public policies and their moral analysis ${ }^{3}$.

In this sense, intervention bioethics also emerged as an anti-hegemonic proposal in the 1990s Latin American scenario ${ }^{25}$. It promotes a contextualized reflection, focused on the social dimension and in line with the dilemmas experienced in public health. Prioritization of policies and solutions that respond to population needs is fundamental in times of pandemic, especially when we have exacerbated impacts on the most vulnerable, including unemployment and decreased income. Decisions taken by governments should favor the largest number of people in order to guarantee the exercise of citizenship by all.

Only together can we go further in these challenging times. Even if there are currently more than 180 nations and economies involved in Covax, a significant gap remains in funding that, if not addressed, will largely undermine Covax's role in providing access to vaccines to low- and middle-income countries ${ }^{26}$. As challenges continue to grow, covid-19 control can and must be accelerated with initiatives like Covax, but everyone needs to truthfully endorse and support it.

\section{Final considerations}

Justice, autonomy and beneficence are the most often cited principles to guide ethical arguments. However, the ones worthy of justice, autonomy and beneficence are still in discussion when critical situations arise, like the present one caused by covid-19. The comprehension that all human beings deserve respect, solidarity, and protection can help pave the way for accelerating pandemic control for all.

A final reflection is to take advantage of this situation to rethink ways of life that place the survival of people, communities and the planet at risk. Reducing risks and threats to public health at the human-animal-ecosystem interface is the proposal of the "One Health" initiative by WHO. Considering governments' measures to guarantee population survival, this could also be the moment to validate policies to guarantee the planet's resources and rescue the ethics of every form of life.

\section{References}

1. Sandel MJ. Justiça: o que é fazer a coisa certa? $18^{a}$ ed. Rio de Janeiro: Civilização Brasileira; 2015.

2. Dawson A, Jennings B. The place of solidarity in public health ethics. Public Health Rev [Internet]. 2012 [acesso 2 dez 2020];34:4. DOI: 10.1007/BF03391656

3. Schramm FR, Kottow M. Principios bioéticos en salud pública: limitaciones y propuestas. Cad Saúde Pública [Internet]. 2001 [acesso 30 nov 2020];17(4):949-56. DOI: 10.1590/S0102-311X2001000400029 
4. Neves DA. O critério utilitarista será adequado para situação de risco? Rev Bras Saúde Mater Infant [Internet]. 2010 [acesso 2 ago 2020];10(supl 2):347-53. DOI: 10.1590/S1519-38292010000600012

5. Mandal J, Ponnambath DK, Parija SC. Utilitarian and deontological ethics in medicine. Trop Parasitol [Internet]. 2016 [acesso 30 nov 2020];6(1):5-7. DOI: 10.4103/2229-5070.175024

6. Coronavirus: Africa will not be testing ground for vaccine, says WHO. BBC News [Internet]. 6 abr 2020 [acesso 22 jul 2020]. Disponível: https://bbc.in/2NgvBQa

7. Hellmann F, Williams-Jones B, Garrafa V. Covid-19 and moral imperialism in multinational clinical research. Arch Med Res [Internet]. 2020 [acesso 30 jul 2020];51(6):572-3. DOI: 10.1016/j.arcmed.2020.04.017

8. World Medical Association. WMA declaration of Helsinki: ethical principles for medical research involving human subjects [Internet]. 2013 [acesso 16 fev 2021]. Disponível: https://bit.ly/2rJdF3M

9. Garrafa V, Prado MM. Mudanças na Declaração de Helsinki: fundamentalismo econômico, imperialismo ético e controle social. Cad Saúde Pública [Internet]. 2001 [acesso 2 dez 2020];17(6):1489-96. DOI: 10.1590/ S0102-311X2001000600020

10. Hellmann F, Verdi M, Schlemper B Jr, Garrafa V. The revised Declaration of Helsinki: cosmetic changes do not protect participants in poor countries. J R Soc Med [Internet]. 2016 [acesso 30 nov 2020];109(10):367. DOI: 10.1177/0141076816661323

11. United States of America. Department of Health, Education, and Welfare. Office of the Secretary. The National Commission for the Protection of Human Subjects of Biomedical and Behavioral Research. The Belmont Report: ethical principles and guidelines for the protection of human subjects of research [Internet]. Washington: Department of Health, Education, and Welfare; 1979 [acesso 30 jul 2020]. Disponível: https://bit.ly/374f5Kh

12. Organização das Nações Unidas para a Educação, a Ciência e a Cultura. Declaração universal sobre bioética e direitos humanos [Internet]. Paris: Unesco; 2006 [acesso 30 jul 2020]. Disponível: https://bit.ly/3jG6Nxt

13. Nuffield Council on Bioethics. Research in global health emergencies: ethical issues [Internet]. London: Nuffield Council on Bioethics; 2020 [acesso 30 jul 2020]. Disponível: https://bit.ly/2MEvHBz

14. Thomé BC, Larson H. Research in the time of coronavirus: keep it ethical. Stat [Internet]. 2 mar 2020 [acesso 30 jul 2020]. Disponível: https://bit.ly/2Z4UnWi

15. Emanuel EJ, Persad G, Upshur R, Thome B, Parker M, Glickman A et al. Fair allocation of scarce medical resources in the time of covid-19. N Engl J Med [Internet]. 2020 [acesso 22 jul 2020];382:2049-55. p. 2051. DOI: 10.1056/NEJMsb2005114

16. Emanuel EJ, Persad G, Upshur R, Thome B, Parker M, Glickman A et al. Op. cit.

17. The Tuskegee timeline. Centers for Disease Control and Prevention [Internet]. U.S. Public Health Service Syphilis Study at Tuskegee; 2 mar 2020 [acesso 22 fev 2021]. Disponível: https://bit.ly/3euSc7u

18. World Health Organization. Working Group on Ethics and Covid-19. Ethics and covid-19: resource allocation and priority-setting [Internet]. Geneva: WHO; 2020 [acesso 30 jul 2020]. Disponível: https://bit.ly/371 LgKo

19. Launch and scale speedometer. Duke Global Health Innovation Center [Internet]. 15 fev 2020 [acesso 28 fev 2021]. Disponível: https://bit.ly/3eqL8bT

20. Sinha A. Explained: what is vaccine nationalism? Why is it a concern? The Indian Express [Internet]. 3 set 2020 [acesso 19 nov 2020]. Disponível: https://bit.ly/2Z66H8M

21. Chade J. Na pandemia, 99 países defendem fim de patente para vacina; Brasil é contra. UOL [Internet]. 19 nov 2020 [acesso 30 nov 2020]. Disponível: https://bit.ly/374gJM5

22. The Access to Covid-19 Tools (ACT) Accelerator. World Health Organization [Internet]. 2020 [acesso 30 jul 2020]. Disponível: https://bit.ly/3rRRe8G

23. Berkley S. The Gavi Covax AMC explained. Gavi [Internet]. 2020 [acesso 28 fev 2021]. Disponível: https://bit.ly/3cgKXNC

24. Schramm FR. Bioethics of protection: a health practice evaluation tool? Ciênc Saúde Colet [Internet]. 2017 [acesso 30 jul 2020];22(5):1531-8. DOI: 10.1590/1413-81232017225.04532017 
25. Garrafa V. Da bioética de princípios a uma bioética interventiva. Bioética [Internet]. 2005 [acesso 30 nov 2020];13(1):124-34. Disponível: https://bit.ly/3rBByGg

26. Covax announces additional deals to access promising covid-19 vaccine candidates; plans global rollout starting Q1 2021. World Health Organization [Internet]. 18 dez 2020 [acesso 28 fev 2021]. Disponível: https://bit.ly/30xk0Q6

Mariana Cabral Schveitzer - PhD - mariana.cabral@unifesp.br

(D) 0000-0001-9833-2932

Beatriz da Costa Thome - PhD - biathome@gmail.com

(DD 0000-0002-3941-3756

\section{Correspondence}

Mariana Cabral Schveitzer - Rua Botucatu, $740,4^{\circ}$ andar, Vila Clementino

CEP 04023-062. São Paulo/SP, Brasil.

Participation of the authors

Mariana Cabral Schveitzer conceived the study and wrote the article. Beatriz da Costa Thome contributed to the critical analysis and final review.

Received: 8.29 .2020

Revised: $\quad 10.19 .2020$

Approved: 12.5 .2020 